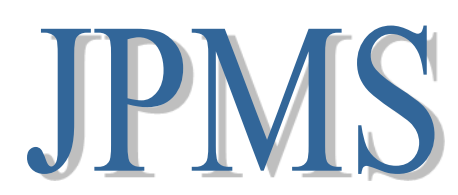

Jurnal Pengabmas Masyarakat Sehat

ARTIKEL HASIL PENGABDIAN KEPADA MASYARAKAT

URL artikel: http://ejournal.poltekkes-denpasar.ac.id/index.php/JPMS/article/view/jpms2406

\title{
Pemberian KIE Dengan Pengetahuan Ibu Nifas Mengenai Infeksi Masa Nifas Di Dusun Kelapa Dua
}

\author{
Dewi Susanti ${ }^{1 k}$; Elen Parengkuan ${ }^{1}$ \\ ${ }^{1}$ Sekolah Tinggi Ilmu Kesehatan Maluku Husada, DIII Kebidanan \\ Email penulis korespondensi $\left({ }^{\mathrm{K}}\right)$ : dsusanti@gmail.com
}

\begin{abstract}
The puerperium begins after the placenta is born and ends when the uterus organs return to their prepregnancy state. The puerperium lasts about 6 weeks or 40 days, but will recover completely within 3 months. The puerperium or postpartum period is also called puerperium which comes from the Latin word "puer" which means baby and "parous "means giving birth. Based on data obtained according to recording and reporting from districts / cities, the maternal mortality rate (MMR / MMR) in Maluku Province fluctuated from 2006 to 2010. However, it decreased from 369 per 100,000 live births in 2006 to 288 per 100,000 births. live in 2010.
\end{abstract}

Keywords: KIE, Knowledge, puerperal infection.

\section{Pendahuluan}

Pengetahuan merupakan faktor yang sangat penting dalam membentuk tindakan seseorang, sehingga kurangnya pengetahuan tentang tanda bahaya pada masa kehamilan dapat mempengaruhi seseorang untuk mempunyai perhatian terhadap keselamatan ibu dan bayi. Jadi pengetahuan ibu tentang tanda bahaya kehamilan merupakan salah satu faktor penting yang mendukung dalam menurunkan tingginya AKI dan AKB di Indonesia ${ }^{(1)}$

Masa nifas (puerperium) dimulai setelah plasenta lahir dan berakhir ketika alat-alat kandungan kembali seperti keadaan sebelum hamil. Masa nifas berlangsung selama kira-kira 6 minggu atau 40 hari, namun secara keseluruhan akan pulih dalam waktu 3 bulan. Masa nifas atau postpartum disebut juga puerperium yang berasal dari bahasa latin yaitu dari kata "puer" yang artinya bayi dan "parous" berarti melahirkan. ${ }^{(2)}$ Masa nifas merupakan masa paling kritis dalam kehidupan ibu, salah satunya disebabkan infeksi nifas. Infeksi nifas adalah peradangan yang terjadi pada organ reproduksi yang disebabkan oleh masuknya mikroorganisme atau virus kedalam organ reproduksi tersebut selama proses persalinan dan masa sesudah persalinan dan kelahiran bayi. ${ }^{(3)}$

Komunikasi, Informasi, dan Edukasi (KIE) adalah proses interaksi dua arah dalam rangka penyampaian informasi antara komunikator (pemberi informasi, dalam hal ini adalah bidan) dan 
komunikasi (yang menerima informasi, yaitu pasien) dengan materi informasi yang berkaitan dengan ibu nifas dan bertujuan untuk peningkatan pengetahuan melalui metode pendidikan kesehatan. ${ }^{(4)}$

Pada tahun 2013 WHO mencatat hampir 800 (99\%) wanita meninggal setiap hari akibat komplikasi pada masa kehamilan dan persalinan dan terjadi di negara-negara berkembang. Di Indonesia upaya penurunan AKI harus difokuskan pada penyebab langsung kematian ibu, yang terjadi $90 \%$ pada saat persalinan, segera setelah persalinan yaitu perdarahan $28 \%$, eklamsi $24 \%$, infeksi $11 \%$, Infeksi pueperium $8 \%$, partus macet $5 \%$, abortus $5 \%$, trauma obstetric $5 \%$, emboli $3 \%$, dan lain lain $11 \%{ }^{(5)}$

Berdasarkan data yang diperoleh sesuai pencatatan dan pelaporan dari Kabupaten/Kota, angka Kematian Ibu (AKI/MMR) di Provinsi Maluku berfluktuasi dari tahun 2006 sampai dengan tahun 2010. Namun mengalami penurunan dari 369 per 100.000 kelahiran hidup pada tahun 2006 menjadi 288 per 100.000 kelahiran hidup pada tahun $2010 .^{(6)}$

\section{Metode Pengabdian}

Kegiatan pengabdian kepada masyarakat dilaksanakan di Dusun Kelapa Dua, pada Tanggal 0914 Maret 2020. Sasaran dari kegiatan pengabdian masyarakat ini adalah ibu nifas yang berada di lokasi penelitian. Kegiatan pengabdian ini berupa pemberian KIE mengenai infeksi masa nifas menggunakan media leaflet, laptop, LCD, kuesioner dan speaker. Kegiatan pengumpulan data akan dilakukan dengan pre-test dan post-test. Teknik pengumpulan data yang digunakan adalah teknik sampling aksidental yaitu siapa saja yang secara kebetulan bertemu dengan peneliti dapat digunakan sebagai sampel penelitian sesuai dengan kriteria inklusi dan eksklusi. Dalam kegiatan pengabdian masyarakat ini pengolahan dan analisis data menggunakan analisis univariat, hasil kuesioner yang didapatkan akan di tabulasi kemudian di analisis secara manual dan dibuatkan pembahasan.

\section{Hasil dan Pembahasan}

\section{A. Hasil}

\section{Hasil Pre-test dan Post-test Pengetahuan Ibu Nifas Mengenai Infeksi Masa Nifas}

Dari hasil data penelitian menunjukan bahwa adanya peningkatan pengetahuan ibu nifas tentang infeksi masa nifas sebesar $66,6 \%$. Pengetahuan ibu nifas mengenai infeksi masa nifas yang benar saat pre-test sebesar $40 \%$, setelah dilakukan penyuluhan mengenai infeksi masa nifas, sampel mendapatkan pemahaman dan pengetahuan sehingga nilai post-test meningkat sebesar $66,6 \%$. Data selengkapnya dapat dilihat pada tabel 1.

Tabel 1. Hasil Pre-test dan Post-test Pengetahuan Ibu Nifas Mengenai Infeksi Masa Nifas

\begin{tabular}{ccccccc}
\hline \multirow{2}{*}{ No } & \multicolumn{3}{c}{ Pre-test } & \multicolumn{3}{c}{ Post-test } \\
\cline { 2 - 7 } & Pengetahuan & $\mathrm{f}$ & $\%$ & Pengetahuan & $\mathrm{f}$ & $\%$ \\
\hline 1 & Baik & 6 & 40,0 & Baik & 10 & 66,6 \\
2 & Kurang & 9 & 60,0 & Kurang & 5 & 33,4 \\
\hline & Jumlah & 15 & 100,0 & Jumlah & 15 & 100,0 \\
\hline
\end{tabular}




\section{B. Pembahasan}

Menurut asumsi peneliti pengetahuan ibu nifas merupakan sesuatu yang diperoleh oleh ibu nifas melalui pengalaman dan interaksi di lingkungannya. Pengetahuan ini akan memengaruhi cara berpikir ibu nifas tentang infeksi masa nifas. Berdasarkan penelitian mayoritas pengetahuan ibu kurang tentang infeksi masa nifas, sebab dipengaruhi oleh tingkat pendidikan ibu nifas yang mayoritas adalah SMA. Pada tingkat pendidikan SMA pola pikir ibu nifas tersebut masih pada tahap mengetahui atau bahkan sedikit yang memahami, sehingga ibu bisa mudah terpengaruh pada sumber informasi yang salah atau kesalahan persepsi ibu yang berimbas pada pengetahuannya tentang infeksi masa nifas.

Kenyataan masih kurangnya pengetahuan tentang masa nifas tentu akan berdampak pada sikap dan perilaku yaitu responden akan sulit untuk menyadari dan melakukan praktek perawatan pada masa nifas sesuai dengan standart kesehatan. Apalagi sebagian besar hidupnya terkungkung oleh adat-istiadat yang masih kuat berpengaruh, sehingga ketika bidan menyampaikan penyuluhan atau informasi akan sulit diterima dan dipahami oleh responden. Kondisi ini menyebabkan bidan bekerja keras dalam memberikan pemahaman tentang infeksi masa nifas agar masyarakat menyadari pentingnya masa nifas, hal mana sangat penting dalam upaya menurunkan AKI. Sesuai dengan teori L. Green yang mengatakan bahwa pendidikan memengaruhi proses belajar, semakin tinggi tingkat pendidikan seseorang maka semakin mudah orang tersebut menerima informasi baik dari orang lain maupun media masa.

\section{Simpulan dan Saran}

Masa nifas merupakan masa yang paling kritis dalam kehidupan ibu, kejadian akan semakin meningkat bila kondisi ibu mengalami gangguan kesehatan, salah satunya disebabkan infeksi nifas. Berdasarkan data yang diperoleh mendapatkan hasil adanya peningkatan pengetahuan ibu nifas sebesar 66,6\%. Sehingga perlu dilakukan KIE (komunikasi, informasi dan edukasi) secara menyeluruh dan berkala oleh tenaga kesehatan kepada ibu nifas dalam memberikan edukasi mengenai infeksi masa nifas sehingga menambah pengetahuan mengenai perawatan masa nifas sesuai anjuran kesehatan.

\section{Daftar Pustaka}

1. Notoatmojo,Soekidjo, Metodologi Penelitian Kesehatan, Rineka Cipta. Jakarta.2012

2. Bahiyatun. Buku Ajar Asuhan Kebidanan Nifas Normal. EGC; 2009.

3. Saryano. Metode Penelitian Kebidanan D3, D4, S1 \& S2. Yogyakarta : Nuha Medika.2010

4. WHO. Maternal Mortality, Media Center 2014. Tersedia pada : http://www.who.int/gho/maternal.he alth/en/

5. Dinas Kesehatan Provinsi Maluku. Profil Dinas Kesehatan Provinsi Maluku. Ambon : 2010

6. Green, L.W. Health Promotion Planning : An Educationnal and Environmental Approach. Second Edition. Mountain View- Toronto London : Mayfieltd Publishing Company.2000 